\title{
高マンガン鋼の疲労強度特性に及ぼす介在物の影響十
}

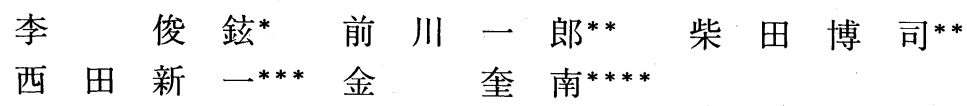

\section{Influence of Inclusions on Characteristics of Fatigue Strength of High Manganese Steel}

\author{
by
Joon-Hyun LeE*, Ichiro MaeKawA**, Hiroshi ShiBATA** Shin-ichi NISHIDA*** and Giu-Nam KIM****

Fatigue experiments were conducted to elucidate the influence of inclusions on fatigue crack growth behavior of high manganese steel at low stress amplitude near the threshold region and in the region II for the temperature range of $297 \mathrm{~K}$ to $113 \mathrm{~K}$. Two series of steel with different inclusion contents were used. Compact tension specimens were prepared in SL or ST orientation with respect to the rolling direction.

The results showed that the fatigue crack growth rate $d a / d N$ of SL specimen was higher than that of ST specimen for both series at low stress levels near the threshold region. On their fracture surfaces, slightly larger roughness was measured in the case of ST specimen compared with the SL specimen and the roughness increased slightly with an increase of the content of sulphide inclusion regardless of experimental temperature. Based on these results, it is considered that $d a / d N$ in this region is affected by the crack closure due to the surface roughness which depends on the inclusion content and on the orientation. In the region II, the influence of orientation on $d a / d N$ was more pronounced than that of content at both $297 \mathrm{~K}$ and $113 \mathrm{~K}$. However, ST specimen with a high inclusion content showed the lower fatigue crack growth rate than the base material at $113 \mathrm{~K}$. In order to make clear this reason, fracture surface were observed by a SEM. It is pointed out that microcracks produced in elongated MnS inclusions increase $d a / d N$ for SL specimen but reduce $d a / d N$ for ST specimen.

Key words : Fatigue crack growth rate, Surface roughness, Threshold, Elongated MnS inclusion

\section{1 緒言}

最近，極低温における大型構造物の実用化が見込ま れ，著者らは低温用構造材料として新しく開発された 高マンガン鋼の低温強度に及ぼす介在物の影響につい て研究を進めてきた。市の結果, 圧延方向に対して LT 方向の試験片では非金属介在物のためにき裂進展 速度が低減すること等が示された。 ところで破壊の起 点にはしばしば非金属介在物が存在したことが報告さ れている. これらのこことから介在物が強度に及ほす影 響はその種類, 形状, 分布方向, 負荷様式並びに温度 条件等によって異なり，まだ完全には解明されていな いと考えられる.

そこで本論文では, 圧延方向に対して SL および ST 方向の試験片を用いて, 下限界領域近傍および第
II 領域での疲労き裂の進展挙動を明らかにした.

\section{2 材料および実験方法}

\section{$2 \cdot 1$ 供試材および試験片}

供試材は $25 \mathrm{Mn}-5 \mathrm{Cr}-1 \mathrm{Ni}$ 鋼である. 標準成分の母 材（以下 $\mathrm{A}$ 材と呼ぶ）の他に $\mathrm{S}, \mathrm{Al}$ 成分の含有量を 調整して介在物の含有量を変えた材料（以下 $\mathrm{B}$ 材と 呼ぶ）を用いた．それらの化学成分と機械的性質を Table I と II に示す.これらの材料は, 圧延比 8 で圧 延を行い, $1173 \mathrm{~K}$ に 1 時間保持して溶体化処理を 行った。 そのオーステナイト組織の平均結晶粒径は約 $22 \mu \mathrm{m}$ であった. 介在物は JISG00555 規定の A 型が 多く， B， C 型のものも観察された. 介在物の大きさ の分布の測定結果を Fig. 1 に示す。この図から A, B 両材ともに MnS のような圧延方向に長く伸びた A

\footnotetext{
$\dagger \quad$ 原稿受理 昭和63年12月19日 Received Dec. 19, 1988

* 学生会員 東北大学工学部 仙台市荒巻字青葉, Faculty of Engineering, Tohoku University, Aramaki-Aoba, Sendai

** 正会員 東北大学工学部 仙台市荒巻字青葉, Faculty of Engineering, Tohoku University, Aramaki-Aoba, Sendai

*** 正会員 (株)新日本製鉄八幡中央研究所, 北九州市八幡, Nippon Steel Corp., Central R \& D Bureau, Yawata R \& D Lab., Yawata, Kitakyushu

**** 釜山大学校工科大学 韓国釜山市金井区, College of Engineering, Pusan National University, Pusan, Korea
} 
Table I. Chemical composition.

(wt \%)

\begin{tabular}{c|c|c|c|c|c|c|c|c|c|c}
\hline Series & $\mathrm{C}$ & $\mathrm{Si}$ & $\mathrm{Mn}$ & $\mathrm{P}$ & $\mathrm{S}$ & $\mathrm{Cr}$ & $\mathrm{Ni}$ & $\mathrm{Al}$ & $\mathrm{Nb}$ & $\mathrm{N}$ \\
\hline $\mathrm{A}$ & 0.21 & 0.24 & 24.43 & 0.024 & 0.01 & 4.99 & 1.10 & 0.004 & 0.05 & 0.038 \\
\hline $\mathrm{B}$ & 0.21 & 0.25 & 24.2 & 0.024 & 0.024 & 4.76 & 1.09 & 0.011 & 0.05 & 0.037 \\
\hline
\end{tabular}

Table II. Mechanical properties.

\begin{tabular}{c|c|c|c|c}
\hline Series & $\sigma_{0.2} \mathrm{MPa}$ & $\sigma_{\mathrm{B}} \mathrm{MPa}$ & $\begin{array}{c}\text { Elongation } \\
\phi \%\end{array}$ & $\begin{array}{c}\text { Reduction of } \\
\text { Area, } \Phi \%\end{array}$ \\
\hline $\mathrm{A}$ & 298 & 710 & 57.3 & 61.9 \\
\hline $\mathrm{B}$ & 246 & 660 & 53.0 & 55.7 \\
\hline
\end{tabular}

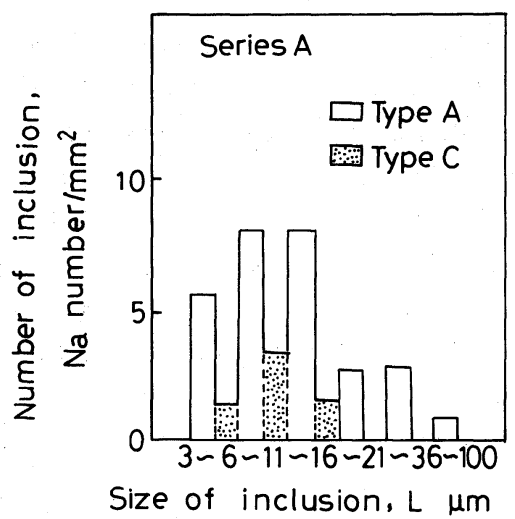

(a) Series A steel.

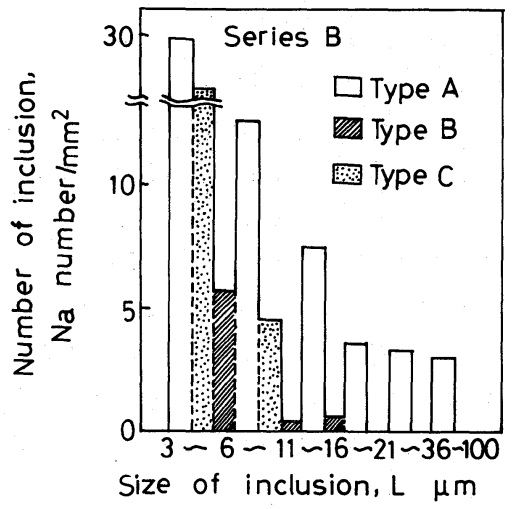

(b) Series B steel

Fig. 1. Histograms of the distribution of inclusion size.

型介在物が多く, B 材では $\mathrm{A}$ 材の約 2.5 倍も多い. 特に約 $4 \mu$ 程度のものは約 6 倍も多くなっている.

試験片は厚さ $12.5 \mathrm{~mm}$ の 1 インチ $\mathrm{CT}$ 試験片であ る. その採取方向は非金属介在物の応力集中効果が顕 著に表われると予想される $\mathrm{SL}$ および ST 方向とし た.

\section{$2 \cdot 2$ 実験方法}

疲労実験は能力 $98 \mathrm{kN}$ の油圧サーボ試験機であり, 最大荷重 $4.9 \mathrm{kN}$, 荷重比 $R=0.1$ の三角波を $10 \mathrm{~Hz}$ で 作用させた。 下限界応力拡大係数範囲 $\Delta K_{\mathrm{th}}$ は $\Delta K$ 漸
減法によって求めた。低温実験には低温槽を用い, $\pm 2 \mathrm{~K}$ 以内で温度制御をした.

\section{3 実験結果と考察}

\section{$3 \cdot 1$ き裂進展の下限界近傍における進展挙動}

き裂進展速度 $d a / d N$ に対する介在物の方向性と含 有量の影響に関する研究は主に $\Delta K$ のレベルが比較 的高い第 II 領域で行われ，降伏強度 $\sigma_{\mathrm{y}}$ が高いほど $d a$

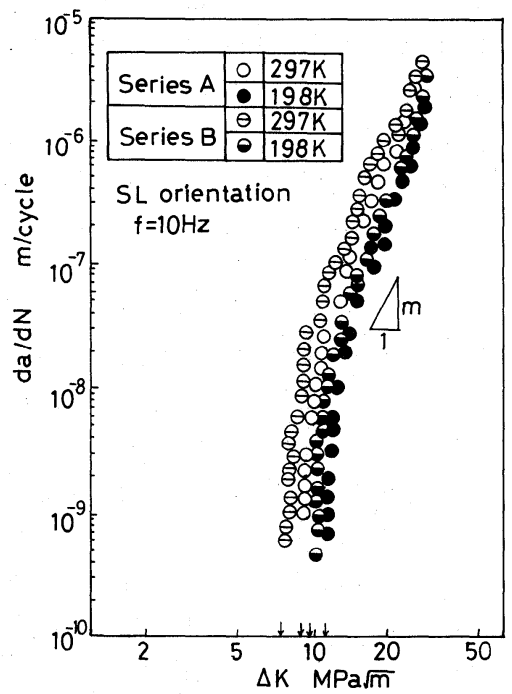

(a) SL specimen.

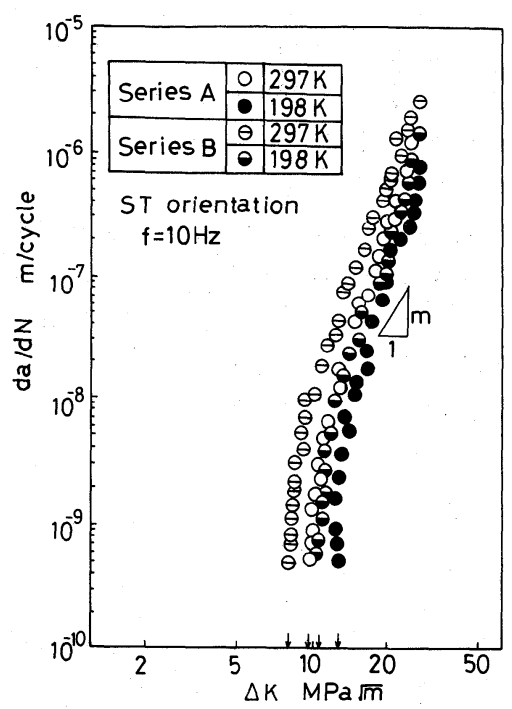

(b) ST specimen

Fig. 2. Fatigue crack growth behaviors of Series $\mathrm{A}$ and $\mathrm{B}$ at near threshold region. 
Table III. Crack tip parameters for fatigue crack propagation (297 K).

\begin{tabular}{c|c|c|c|c|c|c|c}
\hline Material & $\begin{array}{c}\text { Average } \\
\text { grain } \\
\text { size, } \\
d(\mu \mathrm{m})\end{array}$ & $\begin{array}{c}\text { Average } \\
\text { inclusion } \\
\text { distance, } \\
\bar{d}(\mu \mathrm{m})\end{array}$ & Orientation & $\begin{array}{c}\text { Reversed } \\
\text { plastic } \\
\text { zone, } \\
r_{\mathrm{y}}^{\mathrm{c}}(\mu \mathrm{m})\end{array}$ & $\begin{array}{c}\text { Maximum } \\
\text { surface } \\
\text { roughness, } \\
R_{\max }(\mu \mathrm{m})\end{array}$ & $\begin{array}{c}\mathrm{CTOD}_{\max } \\
(\mu \mathrm{m})\end{array}$ & $\begin{array}{c}\mathrm{CTOD}_{\min } \\
(\mu \mathrm{m})\end{array}$ \\
\hline Series A & 22 & $\bar{d}_{\mathrm{A}}=18$ & $\mathrm{SL}$ & 22 & 75 & 0.7 & 0.4 \\
\cline { 5 - 9 } & & $\bar{d}_{\mathrm{c}}=23$ & $\mathrm{ST}$ & 13 & 84 & 0.6 & 0.3 \\
\hline \multirow{2}{*}{ Series B } & 21 & $\bar{d}_{\mathrm{A}}=10$ & $\mathrm{SL}$ & 31 & 86 & 0.8 & 0.4 \\
\cline { 5 - 8 } & & $\bar{d}_{\mathrm{c}}=39$ & $\mathrm{ST}$ & 26 & 110 & 0.8 & 0.4 \\
\hline
\end{tabular}

$/ d N$ への方向性の影響が顕著に現れている。 ${ }^{8), 10)}$ しかし 下限界近傍についての報告は少なく, 相反する結果も も ある.この点を明らかにするため, Fig. 2 (a)，(b)に $d a / d N$ が $10^{-10} \sim 10^{-5} \mathrm{~m} /$ cycle $の$ 比較的遅い範囲で の本実験結果を示す。これらの図によれば B 材の方 が $\mathrm{A}$ 材よりも採取方向, 温度によらずき裂進展速度 が速い．また同図 (a) と (b)を比べてみると A，B 材 ともに SL 方向材の方が $\mathrm{ST}$ 方向材よりも $d a / d N$ が 大きい. さらに $d a / d N$ が $10^{-8} \sim 10^{-6} \mathrm{~m} /$ cycle の範 囲に対してParis 則の指数 $m$ 值を最小自乗法によっ て求め, $\mathrm{A}$ 材に対する $\mathrm{B}$ 材の $m$ 值の比を $m_{\mathrm{B}} / m_{\mathrm{A}}$ と して $297 \mathrm{~K}, 198 \mathrm{~K}$ における值の比較をしてみると $\mathrm{SL}$ 方向材では各々 $1.07,1.08$ となり, ST 方向材で は $1.12,1.21$ となる. 従って ST 方向材の方が低温 になると介在物量の増加によるき裂進展速度は最も大 きくなることが分かる.

本材料のように多量の介在物を含む場合には, き裂 は進展過程で介在物から相互干渉を受けると考えられ る. Mayesによれば, き裂先端に存在する介在物先 端の弾性ひずみ集中は SL 方向材および ST 方向材 ではそれぞれ LT 材の約 10 倍および 4 倍程度大きい. そこで Table III にき裂先端の応力状態に関連すると 思われる幾つかの因子をまとめて示し考察を行ってみ る. 介在物間の平均距離 $\bar{d}$ は次式を用いて求めた.

$$
\bar{d}=(N / A)^{1 / 2}
$$

ここに, $N$ は観察面積 $A$ 内に含まれる介在物の数で あり, き裂先端の繰返し塑性域の大きさ $r_{\mathrm{y}}^{\mathrm{c}}$ および疲 労き裂先端の最大, 最小開口変位 (CTOD) $\max$ と $(\mathrm{CTOD})_{\min }$ は次式により求めた。

$$
\begin{aligned}
& r_{\mathrm{y}}^{\mathrm{c}}=\frac{1}{3 \pi}\left(\frac{\Delta K_{\mathrm{th}}}{2 \sigma_{\mathrm{y}}}\right)^{2} \\
& (\mathrm{CTOD})_{\max }=\frac{0.5}{E \sigma_{\mathrm{y}}} \frac{\Delta K_{\mathrm{th}}^{2}}{(1-R)^{2}} \\
& (\mathrm{CTOD})_{\min }=\frac{0.5}{E \sigma_{\mathrm{y}}}\left[\frac{\Delta K_{\mathrm{th}}^{2}}{(1-R)^{2}}-\frac{\Delta K_{\mathrm{th}}^{2}}{2}\right]
\end{aligned}
$$

ここに $\sigma_{\mathrm{y}}$ は降伏強度, $R$ は応力比, $E$ は縦弾性係数 である. Table III によれば $r_{\mathrm{y}}^{\mathrm{c}}$ は B 材の方が SL, $\mathrm{ST}$ 両方向材共に A 材より大きく, また SL 方向材 の方が ST 方向材より大きい. また A，B 材におけ る各介在物間の平均距離を見ると $\mathrm{A}$ 材の塑性領域内
には約 $18 \mu$ 程度の間隔で分布している $\mathrm{A}$ 型介在物を 含み, その大きさはFig. 1(a)に示したように $6 \sim 16 \mu$ 程度の可能性が高い.しかし B 材では両方向材とも $に r_{\mathrm{y}}^{\mathrm{c}}$ は平均結晶粒の大きさ $d$ および介在物間の平均 距離 $\bar{d}_{\mathrm{A}}, \bar{d}_{\mathrm{c}}$ に比べて大きいため塑性領域内には $\mathrm{A}$ 型 も C 型介在物も含まれることになり，それらの大き さは Fig. 1 (b) によれば $3 \sim 6 \mu$ 程度の可能性が高い. 従って $297 \mathrm{~K}$ の下限界領域近傍における疲労き裂進 展挙動は, $\mathrm{A}$ 材では主に $10 \mu$ 程度の $\mathrm{A}$ 型介在物に, $\mathrm{B}$ 材は $4 \mu$ 程度の $\mathrm{A}, \mathrm{C}$ 型介在物の両方に影響される と考えられる。

き裂が進展して $\Delta K$ が大きくなれば塑性領域の大 きさ $r_{\mathrm{y}}^{\mathrm{c}}$ も次第に大きくなり, 進展に関与する介在物 の数が増すと共にその中に含まれる介在物の大きさの 範囲も大きくなるであろう．そのため第 II 領域に入る と, き裂進展に対する各介在物の方向や大きさの影響 が顕著に現れてくることが予想される。

\section{$3 \cdot 2$ 下限界領域近傍でのき裂進展挙動に及ぼす伸} 長形 $\mathbf{A}$ 型介在物および表面粗さの影響

一般に $\Delta K_{\mathrm{th}}$ 近傍での疲労き裂進展挙動は材料の組 織に钽感であり，特にき裂の閉口挙動が大きく影響す ることが報告されている。 しかし $\Delta K_{\mathrm{th}}$ 值に対する非 金属介在物の影響については相反する報告も位あるので, この点を明らかにするために触針式表面粗さ計を用い て試験片の破面中央部における表面粗さの測定を試み た.

その測定例をFig. 3 に示す. 凸部と凹部の差の最大 值を $R_{\max }$ として, $297 \mathrm{~K}$ と $198 \mathrm{~K}$ における $\mathrm{SL} よ$ び ST 方向材の $R_{\text {max }}$ を測定し, 単位面積当りの $\mathrm{A}$ 型 介在物の数 $N_{\mathrm{s}}$ との関係を示すと Fig. 4 のようになる. 各測定点は試験片 2 個ずつによる平均值を示す.この

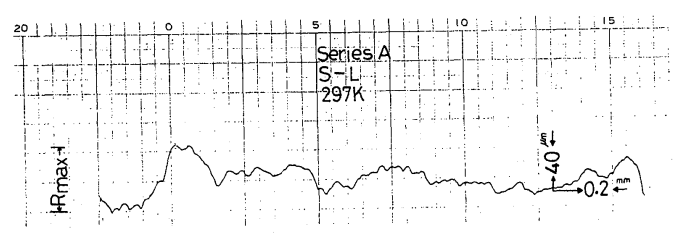

Fig. 3. Typical example of roughness on a fracture surface. 


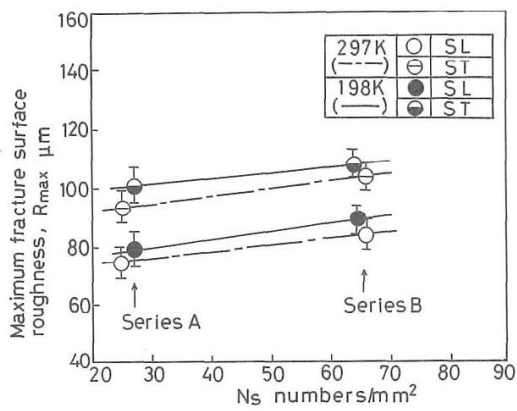

Fig. 4. Relation between the maximum roughness on a fracture surface and number of sulphide inclusion per unit area.

結果をみると $R_{\max }$ の値は実験温度によらず $N_{\mathrm{s}}$ の増 加に伴って増して㧍り，ST 方向材の方が SL 方向材 よりも大きい。この理由を明らかにするためにB 材 の SL，ST 両方向材の $198 \mathrm{~K}$ に扔ける下限界近傍で の破面の SEM 観察を行った例を Fig. 5 に示す。各方 向材共に伸長形 MnS 介在物の存在が明らかに観察さ れ，ST 方向材の方が SL 方向材よりも破面粗さがや や粗く見える。またFig. 5 (a)の (A) 領域内のような長 己 $4 \sim 10 \mu$ 程度の比較的小さい $\mathrm{MnS}$ 介在物の集団が 局部的に観察され，その付近では介在物間の相互連結 により平坦なぜい性破面を形成している。しかし同図 (b) の ST 方向材では介在物の周辺はせん断モードの 破面になっている。このような破面の粗さの相違があ れば， $R_{\max }$ の大きい $\mathrm{ST}$ 方向材は SL 方向材よりも 除荷過程においてき裂閉口が早期に生じることになる. そのために有効応力拡大俰数 $\Delta K_{\text {eff }}^{22)}$ が SL 方向材より も小さくなり， $d a / d N$ が SL 方向材より小さくなっ たものと考えられる。本研究ではき裂閉口を実測して いないが, $\Delta K$ 值の減少は破面粗さに伴うき裂閉口の 効果が増すことによるという報告文之同様の傾向になっ ている．この他に，粗い破面を形成するためにより大 きいエネルギーを要することも $d a / d N$ 低下の一因と

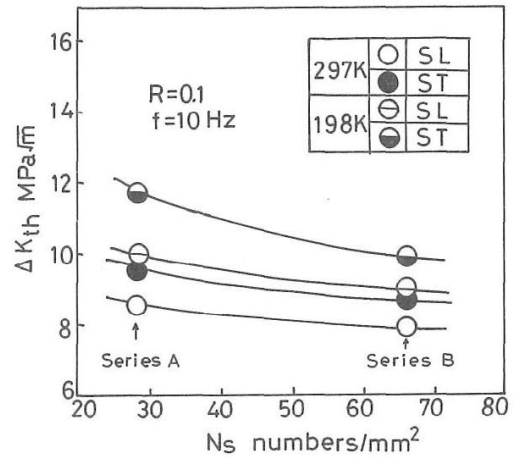

Fig. 6. Relation between threshold stress intensity factor range and number of sulphide inclusion per unit area.

なったものと考えられる.

そこで Fig. 6 に $\mathrm{N}_{\mathrm{s}}$ と $\Delta K_{\text {th }}$ の関係を示すと， $\Delta K_{\text {th }}$ 値は $N_{\mathrm{s}}$ が增せば低下し，297 K, $198 \mathrm{~K}$ ともに SL 方 向材よりも ST 方向材の方が大きく，また温度の低 い方が大きい。

\section{3・3 第吕領域における疲労き裂進展挙動}

$\Delta K_{\text {th }}$ が $N_{\mathrm{s}}$ の影響を受けることからき裂成長開始 には介在物の存在が起因として效いていると考えられ るが，き裂が次第に成長して行くと，その前方に分布 している介在物の回りにも繰返し応力下で微小き裂が それぞれの応力集中の程度に応じて生じて，主き裂と の相互干渉や合体等によりその伝ぱに関わるものと考 えられる。そこで，き裂が安定成長に入った第領域 のき裂進展挙動に及ほす介在物の影響を考察してみる.

Fig. 7 (a)，(b)には $d a / d N$ と $\Delta K$ の関係を示すが, 比較のため LT 材の結果も六してある.この図にお いて, $d a / d N$ は SL 方向の方が ST 方向材よりも大 きく, SL, ST 両方向材共に LT 方向材上り大きい ことが分かる。また Fig.7 (a)に抢いては A 材と B 材 との差はあまりなく，むしろ SL と ST 方向材との 差が明らかにみられる。すなわち, 介在物の含有量よ

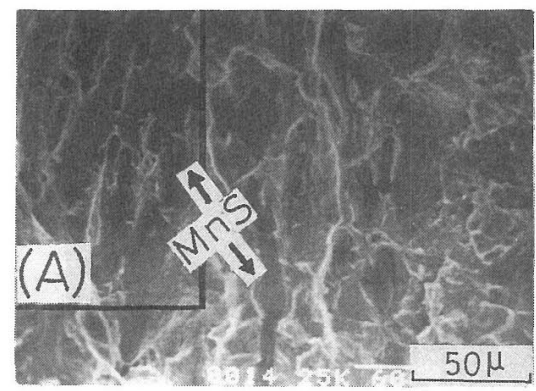

(a) SL Specimen.

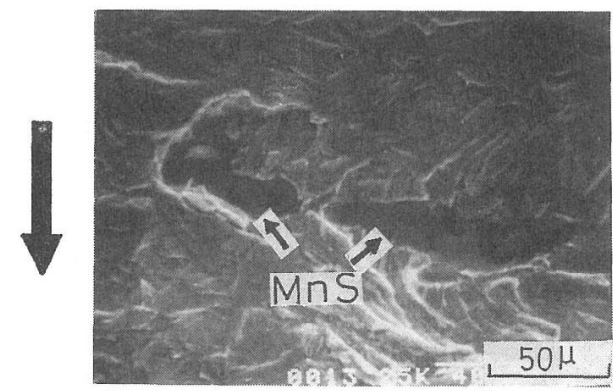

(b) ST Specimen.

Fig. 5. Fracture surfaces near threshold for Series B, 198K $(\Delta K=16 \mathrm{MPa} \sqrt{\mathrm{m}})$. Short arrows indicate the elongated $\mathrm{MnS}$ inclusions and a long arrow shows the direction of fatigue crack propagation. 


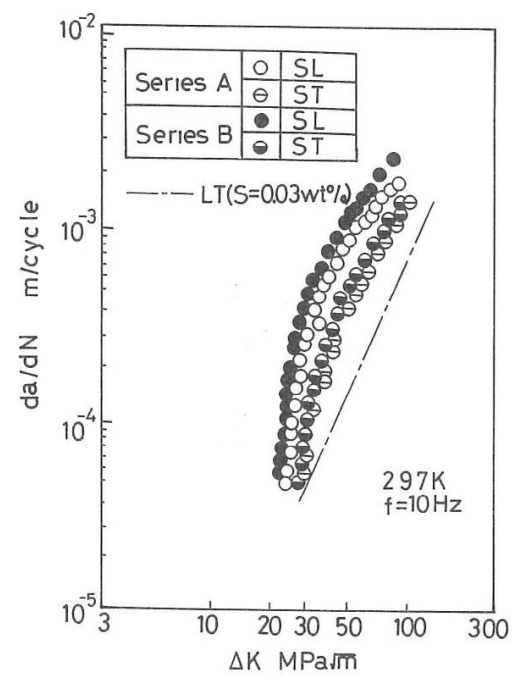

(a) $297 \mathrm{~K}$.

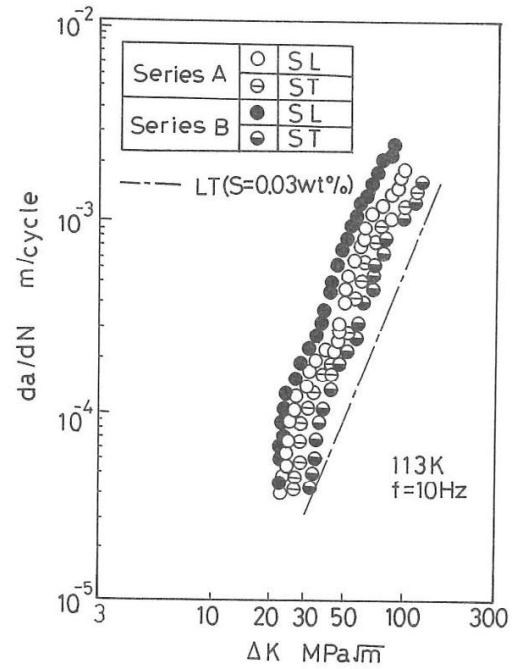

(b) $113 \mathrm{~K}$

Fig. 7. Fatigue crack growth behaviors for Series A and B.

りも分布方向による $d a / d N$ の差が大きいことになる。 な扮 Fig. 7 (b)に扔いてもほぼ同様な傾向がみられる。 ただし，113 K に扮いてはB 材の ST 方向材の $d a$ $/ d N$ はむしろ A 材の $\mathrm{ST}$ 方向材上りも小さい。この 考察のため破面の観察を行った。

Fig. 8 は $\Delta K=40 \mathrm{MPa} \sqrt{\mathrm{m}}$ に扔ける $\mathrm{B}$ 材の両方向 材に対し, $297 \mathrm{~K}$ 抢よび $113 \mathrm{~K}$ での破面の走查電顕写 真を示す。 (a) と (b) は SL 方向材, (c) と (d) は ST 方 向材に対するもので，(a) と (c) は $297 \mathrm{~K}$ に扔ける破面 を，(b)と (d) は $113 \mathrm{~K}$ での破面を示す．また大きい矢 印はき裂進展方向を示し，短い矢印は微小き裂を示し ている。同図(a)の $297 \mathrm{~K}$ での SL 方向材には介在物 周辺の母相内にき裂進展方向のストライエーションが 見られるが，主き裂の進展はその方向に伸びた介在物 の破壞によって促進されたものと考えられる。これに 対して同図 (c)の ST 方向材では介在物は主き裂進展

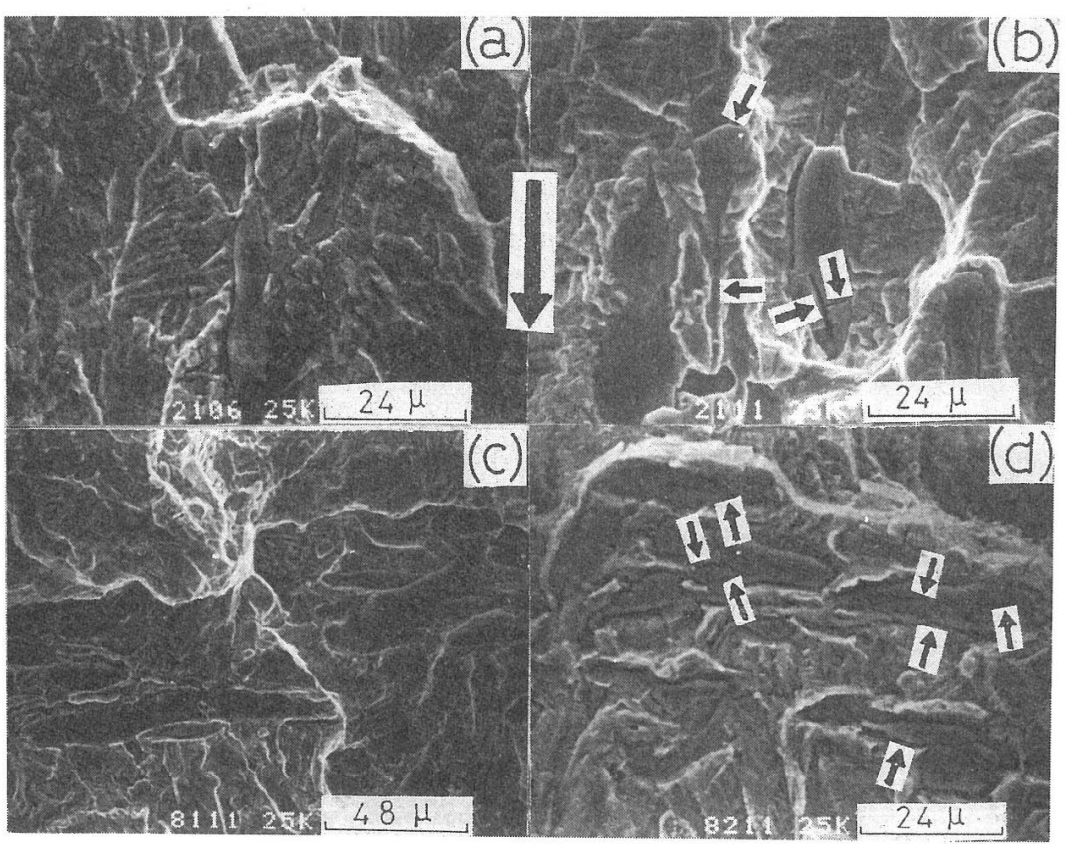

(a) SL, $297 \mathrm{~K}, \Delta K=40 \mathrm{MPa} \sqrt{\mathrm{m}}$. (c) $\mathrm{ST}, 297 \mathrm{~K}, \Delta K=40 \mathrm{MPa} \sqrt{\mathrm{m}}$. (b) SL, $113 \mathrm{~K}, \Delta K=42 \mathrm{MPa} \sqrt{\mathrm{m}}$.

(d) $\mathrm{ST}, 113 \mathrm{~K}, \Delta K=42 \mathrm{MPa} \sqrt{\mathrm{m}}$.

Fig. 8. Fracture surfaces at regime II for Series B (Short arrows in (b) and (d) indicate microcracks in $\mathrm{MnS}$ inclusions at $113 \mathrm{~K}$, a long arrow shows the direction of crack propagation). 
方向に直角になっていて，母相には局部的にストライ エーションがみられるが方向は乱れておりむしろ主き 裂進展速度を低下させたものと考えられる，また，低 温では同図 (d) 中に小矢印で示したような介在物の割 れが生じ，それが(b)のように主き裂の進展方向と同 一方向の SL 材では主き裂の進展を局部的に加速さ せるが, (d)のように主き裂の進展方向にほぼ直角に 多数分布している ST 材ではむしろ主き裂の伝ぱを 阻止することになり，A 材よりもむしろ介在物の量 の多いB 材の方が Fig. 7 (b) のように $d a / d N$ を減少 させたものと考えられる.このような介在物がき裂の 分岐を生じさせ主き裂進展を抑制させることはすでに $\mathrm{Al}$ 合金の場合の報告がある。 なお $\mathrm{A}, \mathrm{B}$ 材いずれも LT 材の場合のような介在物の周囲に主き裂が回り込 んだストライエーションの模様は見られなかった.

\section{4 結言}

以上の結果をまとめると次のようになる.

(1) 下限界領域近くでの疲労き裂進展速度 $d a / d N$ はき裂進展方向に伸びた介在物を含有する SL 方向 材の方が A，B 材共にST 方向材よりも大きい. ま た B 材よりも $\mathrm{A}$ 材の方がかなり小さい.

（2）両方向材共に単位面積当りの $\mathrm{A}$ 型硫化物介在 物の数 $\mathrm{N}_{\mathrm{s}}$ の増加に伴い実験温度によらず破断の表面 粗さ $R_{\max }$ がやや増加した. SL，ST 両方向材の下限 界領域での破面観察の結果，ST 方向材の方が SL 方 向材よりも破面の粗さが大きくなっており，このこと から下限界近くで $d a / d N$ の差を生じたのは, 破面の 粗さの差によるき裂閉口量の相違が影響したものと考 えられる。

（3）き裂伝ぱの第 II 領域における $d a / d N$ は, 介在 物の含有量よりも分布方向の影響の方が大きい.

(4) 第 II 領域の $d a / d N$ に対する介在物の影響は $\mathrm{A}$, $\mathrm{B}$ 材共に下限界領域近傍より大きく，温度によらず ST および SL 両方向材とも LT 方向材よりも大きい. しかし介在物量の多いB 材は, $113 \mathrm{~K}$ において ST 方向材の $d a / d N$ がむしろ $\mathrm{A}$ 材よりも小さくなった. これは B 材は $113 \mathrm{~K}$ において多数の微小き裂が $\mathrm{MnS}$ 介在物の回りに生じたため $d a / d N$ はむしろ A 材よ り小さくなったものと考えられる.

\section{付 録}

結論(2)については, B 材の SL, ST 両方向材に対 して, き裂閉口時の応力拡大係数 $K_{\mathrm{cl}}$ の $K_{\max }$ に対す る比を, 超音波エコー法と除荷弾性コンプライアンス 法を併用して評価した．前者は探触子の取付け条件の 相違が影響して正確な值が得られなかったが, 後者に よって得られた結果は下記の通りであった。

この結果も，ST 方向材ではき裂進展に対して有効 なき裂開口量が減少していることを示している.
(288 K)

\begin{tabular}{c|c|c|c}
\hline & $K_{\mathrm{c} 1} / K_{\max }$ & $\Delta K(\mathrm{MPa} \sqrt{\mathrm{m}})$ & $d a / d N(\mathrm{~m} /$ cycle $)$ \\
\hline SL 方向材 & 0.36 & 11.7 & $4.7 \times 10^{-9}$ \\
& 0.36 & 11.9 & $1.2 \times 10^{-8}$ \\
ST 方向材 & 0.66 & 11.0 & $1.4 \times 10^{-8}$ \\
& 0.62 & 11.7 & $2.0 \times 10^{-8}$ \\
\hline
\end{tabular}

終わりに，本研究を遂行するに当り試験片の御提供 を頂いた新日本製鉄株式会社と御支援を頂いた同社中 央研究本部八幡技術研究部の末宗賢一郎主任研究員に 謝意を表する次第である.

（昭和63年11月 8 日 第19回疲労シンポジウムにて講演）

\section{参 考 文 献}

1) H. Yoshimura, H. Masumoto and T. Inoue, Advances in Cryogenic Engng Materials, 28, 115 (1982).

2) T. Yokobori, I. Maekawa, Y. Tanabe, Z. Jin and S. Nishida, ASTM STP 857, 121 (1985).

3) I. Maekawa, Y. Tanabe, J. H. Lee and S. Nishida, Engng Frac. Mech., 5, 557 (1987).

4 ) I. Maekawa, J. H. Lee and S. Nishida, Fatigue "87", EMAS, Warley, U. K., II, 911 (1987).

5 ) Y. W. Cheng, H. I. McHenry, P. N. Li, T. Inoue and T. Ogawa, Advances in Cryogenic Engng Materials, 30, 303 (1984).

6 ) 大路清嗣, 小倉敬二, 原田昭治, 田路 勉, 日本機械学 会論文集，43，374（1977）。

7 ) 鹿毛正治, 西谷弘信, 日本機械学会論文集, 43, 374 (1977).

8 ) A. D. Wilson, ASTM STP 733, 166 (1981).

9) ASTM Standard Designation, E647-787 (1981).

10) A. D. Wilson, ASME, 101, 265 (1979).

11) I. C. Mayes and T. J. Baker, Materials Science and Technology, 2, 133 (1986).

12) D. Broek, Engng Frac. Mech., 5, 55 (1973)

13) C. J. Beevers, Fatigue " 81 ", I, 257 (1981).

14) H. Gu and X. D. Liu, Fatigue "87", II, 769 (1987).

15) W. Yu, K. Esaklul and W. Gerberich, Metall. Trans. 15A, 889 (1984).

16) P. K. Liaw and W. A. Logsdon, Fatigue " 87 ", II, 899 (1987).

17) I. C. Mayes and T. J. Baker, Fatigue of Engng Materials and Structure, 4, 79 (1981).

18) R. O. Ritchie, Fatigue "81", II, 503 (1981).

19) G. J. Fowler, Material Science and Technology, 2, 133 (1986).

20) K. Hamberg, J. Wasen and B. Karlsson, Fatigue " 87 ", I, 135 (1987).

21) A. J. McEvily, NASA, TDD 328, April (1962).

22) S. Suresh and R. O. Ritchie, Metall. Trans. 13A, 1627 (1982). 